\title{
SIKAP APRESIASI KREATIF SISWA DALAM MEMPELAJARI KARYA SASTRA UNTUK MENINGKATKAN RESPONS KEJIWAAN SISWA TERHADAP KARYA SASTRA PADA MATA PELAJARAN BAHASA INDONESIA KELAS IVA SDN 144 PEKANBARU
}

\author{
Chamsriana Chamsriana* \\ Sekolah Dasar Negeri 144 Pekanbaru \\ “jtachamsriana@gmail.com
}

\begin{abstract}
This study aims to look at the attitude of creative appreciation of students in studying literature to improve students' psychiatric responses to literature in Indonesian students. The design of this study is classroom action research with three cycles. The research subjects are fourth grade students with a total of 25 people. The results showed the attitude of students' creative appreciation in interpreting behavior, the nature of sensitivity and capturing ideas of literary works can be raised in students slowly during the learning process and increase every cycle. Then the students' psychological responses in interpreting behavior, the nature of sensitivity and capturing ideas of literary work can motivate students both internally and externally so that results are improved.
\end{abstract}

Keywords: attitude of appreciation, psychiatric response, literary works

\section{PENDAHULUAN}

Memahami suatu sastra secara implisit, perlu adanya pemahaman terhadap nilai-nilai kehidupan yang ada dimasyarakat, baik secara religi, budaya, ekonomi, politik dan pendidikan. Hakikat sastra dimana melektakkan suatu ciptaan karya sastra kedalam kontruksi pemikiran yang imajinatif. Karya sastra dapat dijadikan sebagai media komunikasi simbolik, dimana bisa sebagai hiburan, renungan, bahan pelajaran dan pembuka paradigma berpikir. Karya sastra yang dipelajari oleh siswa dalam pembelajaran di sekolah bisa melalui kepada proses pembelajaran melalui aktivitas yang dapat dilhat dari membaca puisi, memberi tanggapan dalam membaca puisi, mengubah puisi kedalam proses, membuat pantun, membaca dan memahami isi pantun.

Rozak (2011) bahwa karya sastra selalu membuka peluang dialog dengan pembacanya. Teks pada umumnya membuka kemungkinan mengajak dialog 
kepada pembacanya. Dalam dialog itu berbagai tafsiran akan muncul dan tafsiran pembaca dipengaruhi oleh pengetahuan sebelumnya (pengetahuan, pengalaman, dan perasaan). Sastra merupakan suatu kegiatan kreatif.

Tujuan pokok dalam pembelajaran sastra adalah mencapai kemajuan seorang siswa melalui kemampuan apresiasi kreatif berupa respon sastra yang dilihat dari aspek kejiwaan pada perasaan, imajinasi dan daya kritis. Aminudin dalam Umar (2017) mengemukakan, apresiasi mengandung makna pengenalan melalui perasaan atau kepekaan batin, dan pengakuan terhadap nilai-nilai keindahan yang diungkapkan pengarang. Apresiasi terhadap suatu karya dapat terjadi melalui berbagai tingkatan. Pada umumnya, para ahli sastra membagi tingkatan apresiasi tersebut atas empat bagian yang meliputi: (1) tingkat menggemari, (2) tingkat menikmati, (3) tingkat mereaksi, dan (4) tingkat memproduksi.

Sastra adalah hasil kegiatan kreatif manusia dalam mengungkapkan penghayatannya terhadap kehidupan dan dunia dengan menggunakan bahasa. Jika dicermati, pernyataan tersebut mengandung dua hal yang menjelaskan hakikat sastra. Pertama, "mengungkapkan penghayatan" dan yang kedua "kegiatan kreatif". Aminudin (2010) dan Sumarjo (1988) menjelaskan bahwa apresiasi sastra merupakan kegiatan memahami, menikmati, menilai dan memberikan penghargaan pada karya sastra dan diharapkan dapat membuahkan hasil apresiasi sastra yang tepat, utuh. Oleh karena itu, pemahaman perlu dilandasi prinsip-prinsip dalam kajian sastra maupun pemahaman hasil- hasil karya sastra

Apresiasi sastra adalah kegiatan mengakrabi karya sastra dengan sungguh-sungguh. Di dalam proses pengakraban itu terjadi pengenalan, pemahaman, penghayatan, dan setelah itu penerapan. Dalam mempelajari karya sastra perlu adanya respon yang bisa diberikan kembali oleh siswa dalam proses pembelajaran. Menurut Soekanto (1993) Abidin (dalam Susanto, 1997): Harvey dan Smith (dalam Ahmadi, 2009) respon sebagai perilaku yang merupakan konsekuensi dari perilaku yang sebelumnya sebagai tanggapan atau jawaban suatu persoalan atau masalah tertentu. 
Berdasarkan hal di atas perlu adanya penelitian yang berjudul sikap apresiasi kreatif siswa dalam mempelajari karya sastra untuk meningkatkan respon kejiwaan siswa terhadap karya sastra pada mata pelajaran Bahasa Indonesia siswa kelas IV SDN 144 Pekanbaru. Tujuan dari tulisan ini sejauh mana respon kejiwaan siswa terhadap karya sastra melalui sikap apresiasi keratif siswa.

\section{METODE PENELITIAN}

Jenis penelitian ini adalah penelitian tindakan kelas yang merupakan suatu bentuk penelitian yang bersifat reflektif dengan melakukan tindakan-tindakan tertentu agar dapat memperbaiki dan atau meningkatkan praktek-praktek pembelajaran di kelas secara lebih profesional. Menurut Wardani (2004); Arikunto (2009) menjelaskan PTK melalui gabungan definisi dari tiga kata yaitu "Penelitian" + "Tindakan" + "Kelas". Sedangkan desain Penelitian Tindakan Kelas terdiri dari beberapa tahap kegiatan yaitu, perencanaan, tindakan, observasi, dan refleksi.

Penelitian ini dilaksanakan di SDN 144 Pekanbaru dengan jadwal penelitian Januari sampai Februari 2018. Objek penelitian siswa kelas IVA berjumlah 25 siswa. Penelitian ini dilaksanakan dengan pelaksanaan tiga siklus. Yang diawali dengan refleksi awal dan dilanjutkan dengan pembuatan instrumen pada perencanaan awal. Selanjutnya pelaksanaan rencana yang telah dibuat bersamaan pengamatan selama proses pembelajaran dan diakhiri refleksi. Hasil refleksi dan pengamatan menjadi catatan dan perbaikan untuk siklus selanjutnya. Instrumen penelitian, silabus, RPP dan LKS, sedangkan instrumen pengumpul data lembar aktivitas guru dan siswa serta hasil tes belajar siswa

Pelaksanaan aktivitsa guu dan siswa selama proses pembelajaran di kelas, perlu adanya observer yang menilai dengan acuan sebagai tabel berikut

Tabel 1. Interval aktivitas guru dan siswa

\begin{tabular}{ll}
\hline$\%$ Interval & Kategori \\
\hline $90-100$ & Sangat baik \\
\hline $80-89$ & Baik \\
\hline $65-79$ & Cukup \\
\hline $55-64$ & Kurang \\
\hline$<54$ & Sangat Kurang \\
\hline
\end{tabular}

Sumber Syahrilfuddin (Guslinda 2018) 


\section{HASIL PENELITIAN}

Dalam melihat keberhasilan seseorang dalam tindakan pada proses pembelajaran, maka data yang diperoleh harus diolah sesuai dengan teknik analisa yang sudah ditetapkan. Selama proses pembelajaran dalam penelitian ini perlu adanya pengamatan terhadap aktivitas guru dan aktivitas siswa. Hasil aktivitas guru selama proses pembelajaran ditampilkan pada tabel berikut

Tabel 2. Aktivitas guru selama proses pembelajaran

\begin{tabular}{lccc}
\hline \multicolumn{1}{c}{ Aspek } & Siklus I & Siklus II & Siklus III \\
\hline Jumlah & 19 & 21 & 22 \\
\hline Skor Maksimum & 24 & 24 & 24 \\
\hline Persentase & $79,16 \%$ & $87,5 \%$ & $91,66 \%$ \\
\hline Kategori & Cukup & Baik & Sangat Baik \\
\hline
\end{tabular}

Berdasarkan tabel di atas terlihat perbandingan aktivitas guru dalam enam kali pertemuan yang secara umum terdapat peningkatan dalam proses pembelajaran. Pada siklus pertama guru memperoleh skor 19 dengan persentase $79,16 \%$ dengan kategori cukup, sedangkan pada siklus kedua guru memperoleh skor 21 dengan persentase $87,5 \%$ dengan kategori baik dan siklus ketiga terdapat peningkatan dengan persentase $91,66 \%$ dengan kategori sangat baik. Dari simpulan tabel tersebut terlihat jelas bahwa guru telah melaksanakan alur kegiatan pembelajaran dengan baik dan cermat.

Tabel 3. Aktivitas siswa selama proses pembelajaran

\begin{tabular}{llll}
\hline Aspek & Siklus I & Siklus II & Siklus III \\
\hline Jumlah & 17 & 20 & 21 \\
\hline Skor Maksimum & 24 & 24 & 24 \\
\hline Persentase & $70,8 \%$ & $83,3 \%$ & $87,5 \%$ \\
\hline Kategori & Cukup & Baik & Baik \\
\hline
\end{tabular}

Berdasarkan tabel 3 terlihat bahwa aktivitas yang diperoleh siswa selama pembelajaran meningkat dari setiap siklusnya. Siklus pertama skor yang diperoleh berjumlah 17 dengan persentase $70,8 \%$ dengan kategori cukup, sedangakan siklus kedua dan ketiga skor yang diperoleh hanya 20 dan 21 dengan persentase $83,3 \%$ dan $87,5 \%$ dengan kategori baik. Dari data tersebut dapat disimpulkan bahwa siswa sudah mulai baik walaupun masih belum mencapai nilai yang terbaik. 
Kemampuan siswa dalam mempelajari karya sastra perlu adanya sikap apresiasi kreatif. Hasil yang diperoleh selama penelitian dijabarkan pada tabel berikut

Tabel. 4. Sikap apresisasi kreatif siswa dalam mempelajari karya sastra

\begin{tabular}{|c|c|c|c|c|c|c|c|}
\hline \multirow{2}{*}{ No } & \multirow{2}{*}{ Apsek } & \multicolumn{2}{|c|}{ Siklus I } & \multicolumn{2}{|c|}{ Siklus II } & \multicolumn{2}{|c|}{ Siklus III } \\
\hline & & $\mathrm{PI}$ & $\mathrm{P} \| \mathrm{I}$ & $\mathrm{PI}$ & $\mathrm{P} \| \mathrm{I}$ & $\mathrm{PI}$ & $\mathrm{P} \| \mathrm{I}$ \\
\hline \multirow[t]{2}{*}{1} & Kemampuan & $\begin{array}{l}48 \% \\
12\end{array}$ & $\begin{array}{r}53 \% \\
(13\end{array}$ & $\begin{array}{c}68 \% \\
17\end{array}$ & $\begin{array}{c}72 \% \\
(18\end{array}$ & $\begin{array}{c}88 \% \\
(22\end{array}$ & $\begin{array}{c}92 \% \\
(23\end{array}$ \\
\hline & $\begin{array}{l}\text { prilaku karya } \\
\text { sastra }\end{array}$ & Siswa) & Siswa) & Siswa) & Siswa) & Siswa) & Siswa) \\
\hline \multirow[t]{2}{*}{2} & $\begin{array}{l}\text { Memiliki sifat } \\
\text { sensitivitas }\end{array}$ & $\begin{array}{c}44 \% \\
(11\end{array}$ & $\begin{array}{c}48 \% \\
(12\end{array}$ & $\begin{array}{c}60 \% \\
(15\end{array}$ & $\begin{array}{l}64 \% \\
(16\end{array}$ & $\begin{array}{c}84 \% \\
(21\end{array}$ & $\begin{array}{c}88 \% \\
(22\end{array}$ \\
\hline & $\begin{array}{l}\text { terhadap karya } \\
\text { sastra }\end{array}$ & Siswa) & Siswa) & Siswa) & Siswa) & Siswa) & Siswa) \\
\hline \multirow[t]{2}{*}{3} & $\begin{array}{l}\text { Kemampuan } \\
\text { siswa }\end{array}$ & $\begin{array}{c}48 \% \\
(12\end{array}$ & $\begin{array}{l}52 \% \\
(13\end{array}$ & $\begin{array}{l}64 \% \\
(16\end{array}$ & $\begin{array}{l}76 \% \\
(19\end{array}$ & $\begin{array}{c}84 \% \\
(21\end{array}$ & $\begin{array}{c}88 \% \\
(22\end{array}$ \\
\hline & $\begin{array}{l}\text { mnenagkap ide } \\
\text { karya sastra }\end{array}$ & Siswa) & Siswa) & Siswa) & Siswa) & Siswa) & Siswa) \\
\hline
\end{tabular}

mempelajari karya sastra terlihat adanya peningkatan yang jelas antara siklus satu sampai siklus ketiga. Karya sastra yang ditampilkan dalam proses pembelajaran tentang puisi, pantun dan drama.

Siklus I materi yang diajarkan dalam proses pembelajaran adalah karya sastra tentang puisi dimana aspek yang dinilai bagaimana kemampuan menginterpretasi prilaku karya sastra antara pertemuan pertama dan kedua terlihat penambahan satu siswa dalam mengintrepetasikannya. Begitu juga pada aspek sifat sensitivitas dan kemampuan siswa dalam menangkap ide karya sastra memiliki penambahan siswa pada pertemuan kedua.

Siklus kedua materi yang diajarkan pada karya sastra yaitu pantun. Data yang terlihat pada tabel terlihat peningkatan dari siklus pertama. Sedangkan hasil yang diperoleh siswa sudah mencapai diatas $50 \%$, dengan jumah siswa sudah mencapai 19 siswa sebanyak $76 \%$ pada kemampuan siswa menangkap ide pantun.

Siklus ketiga siswa yang mendapat nilai yang terbaik sudah mencapai 23 siswa (92\%) pada kemampuan menginterpretasikan prilaku drama. Sedangkan dua aspek yang lain hanya 23 siswa (88\%). 
Selain sikap apresiasi siswa tersebut peneliti juga melaksanakan pengambilan data tentang sikap respon kejiwaan siswa yang disajikan pada tabel berikut

Tabel. 5. Sikap respon kejiwaan siswa dalam mempelajari karya sastra

\begin{tabular}{|c|c|c|c|c|}
\hline No & Aspek & Siklus I & Siklus II & Siklus III \\
\hline 1 & $\begin{array}{l}\text { Kemampuan respon kejiwaan } \\
\text { siswa Menginterpretasi prilaku } \\
\text { karya sastra }\end{array}$ & $\begin{array}{c}52 \%(13 \\
\text { Siswa) }\end{array}$ & $\begin{array}{c}72 \%(18 \\
\text { Siswa) }\end{array}$ & $\begin{array}{c}92 \%(23 \\
\text { Siswa) }\end{array}$ \\
\hline 2 & $\begin{array}{l}\text { Memiliki respon kejiwaan siswa } \\
\text { terhadap sifat sensitivitas } \\
\text { terhadap karya sastra }\end{array}$ & $\begin{array}{c}48 \%(12 \\
\text { Siswa) }\end{array}$ & $\begin{array}{c}64 \%(16 \\
\text { Siswa) }\end{array}$ & $\begin{array}{c}88 \%(22 \\
\text { Siswa) }\end{array}$ \\
\hline 3 & $\begin{array}{l}\text { Kemampuan respon kejiwaan } \\
\text { siswa mnenagkap ide karya } \\
\text { sastra }\end{array}$ & $\begin{array}{c}52 \%(13 \\
\text { Siswa) }\end{array}$ & $\begin{array}{c}76 \%(19 \\
\text { Siswa) }\end{array}$ & $\begin{array}{c}88 \%(22 \\
\text { Siswa) }\end{array}$ \\
\hline
\end{tabular}

Berdasarakan tabel tersebut terlihat bahwa sikap respon tehadap kejiwaan siswa mengalami peningkatan dalam setiap siklus. Hal ini terlihat dari ketiga aspek. Aspek Kemampuan respon kejiwaan siswa Menginterpretasi prilaku karya sastra mengalami peningkatan dari 13 siswa yang respon pada siklus pertama sampai 23 siswa yang memiliki respon kejiwaan pada siklus ketiga.

Aspek Memiliki respon kejiwaan siswa terhadap sifat sensitivitas terhadap karya sastra mengalami peningkatan dari 12 siswa pada siklus pertama dan siklus ketiga 22 siswa sensitiv terhadap karya sastra. Begitu juga aspek Kemampuan respon kejiwaan siswa menangkap ide karya sastra tetap mengalami peningkatan sampai 9 siswa dari siklus pertama sampai siklus ketiga

\section{PEMBAHASAN}

Sikap apresiasi siswa dalam mempelajari karya sastra selama penelitian ini menunjukkan perubahan yang terjadi pada diri siswa. Hal ini terlihat dari data yanga telah diperoleh. Perubahan yang terlhat dari apresiasi siswa terlihat dari motivas selama proses pembelajaran. Kemampuan apresiasi pada sastra dapat termunculkan pada ketiga aspek. Yang ditampilkan, sehingga proses kemmapuan siswa dalam menerima dan mengembangkan ide, sensitivitasnya muncul pada setiap pembelajaran pada setiap siklus. Perubahan pada diri siswa bisa melalui dari faktor internal dan faktor ekternal siswa itu sendiri. 
Faktor internal merupakan faktor yang harus dimunculkan oleh siswa itu sendiri. Hal ini terlihat respon kejiwaan siswa dalam memahami dan mempelajari karya sastra. Dengan dukungan dari dalam diri siswa, maka penjiwaan siswa terhadap karya sastra akan mencapai titik yang terbaik. Faktor internal untuk mampu mengapresiasi sastra yaitu diri sendiri. Begitu juga dengan kemampuan apresiasi sastra. Faktor internal yaitu yang muncul dari dalam diri siswa sendiri seperti, kebutuhan untuk dapat mengapresiasi sastra, pengalaman siswa dalam apresiasi sastra, semakin banyak pengalaman yang mereka peroleh, maka semakin tinggi kemampuan apresiasi sastranya. Selain itu latar belakang siswa itu sendiri, apabila latar belakang mereka mempunyai sifat seni dari kedua orang tua atau keluarga, maka secara tidak langsung siswa mengikuti kegiatan orang tua sehingga terbiasa dengan mengapresiasi sastra,

Faktor internal terdapat juga faktor ekstrenal juga mendukung dalam kemampuan siswa dalam menjiwai karya sastra dimana faktor eksternal yaitu yang muncul dari luar diri siswa, seperti dukungan atau dorongan misalnya dukungan motivasi dari guru atau orang tua terhadap anak akan mempengaruhi segala kemampuan, selain motivasi dukungan berupa benda atau sarana prasarana juga berpengaruh. Apabila sarana dan prasarana kurang memadai maka kemampuan siswa pun akan tersendat dan terhenti, misalkan seorang anak pandai akan puisi tetapi sekolah atau guru tidak menyediakan buku kumpulan puisi atau buku teori tentang puisi, maka anakpun tidak akan tahu bagaimana mengapresiasi puisi, siswa hanya dapat menyairkan sebuah puisi dan membuatnya, belum sampai kepada mengapresiasi.

Penjiwaan siswa terhadap dalam mempelajari karya siswa didukung oleh aktivitas selama prose pembelajaran. Hal ini terlihat guru memunculkan kemampuan siswa dalam mengekplor kegiatan

Selama siswa mengekplor kegiatan penjiwaan tersebut didukung oleh suatu aktivitas selama proses pembelajaran, baik yang dilakukan oleh guru maupun siswa. Aktivitas yang dilaksanakan oleh siswa Selama proses pembelajaran merupakan suatu umpan balik terhadap guru. Aktivitas yang dilakukan oleh siswa selama pembelajaran berupa aktivitas membaca, 
mengeluarkan pendapat, menulis cerita dan menanggapi kegiatan pembelajaran. Hal ini sesuai dengan pendapat Sardiman (2006) aktivitas belajar dapat digolongkan visual activities, oral activities, listening activities, writing activities, motor activities, mental activities dan emotional activities

\section{SIMPULAN}

Berdasarkan hasil pengolahan data, analilsis dan pembahasan yang telah disajikan, diperoleh kesimpulan, yaitu :1) aktivitas guru dan siswa selama proses pembelajaran meningkat dan mampu memunculkan kreatifitas siswa. 2). Sikap apresisasi kreatif siswa dalam Menginterpretasi prilaku, sifat sensitivitas dan menangkap ide karya sastra dapat dimunculkan pada diri siswa secara perlahan selama proses pembelajaran: 3) Respon kejiwaan siswa dalam Menginterpretasi prilaku, sifat sensitivitas dan menangkap ide karya sastra dapat memotivasi siswa baik secara internal maupun secara eksternal sehingga hasil diperoleh meningkat. Diharapkan guru dapat menerapkan kegiatan sikap apresiasi dan kejiwaan siswa dalam memahami materi yang lain pada mata pelajaran bahasa indonesia

\section{DAFTAR PUSTAKA}

Abu, A. 2009. Psikologi Umum. Jakarta: Rieka Cipta.

Aminudin. 2010. Pengantar Apresiasi Karya Sastra. Bandung: Sinar Baru Aglesindo

Arikunto, S., Suhardjono, dan Supardi. 2009. Penelitian Tindakan Kelas. Jakarta: Bumi Aksara.

Guslinda dan Gustimal Witri. 2018. Penerapan Model Pembelajaran Kooperatif Tipe Make A Match untuk Meningkatkan Hasil Belajar IPS Siswa: Jurnal Tunjuk Ajar, 1(1), hlm 1 - 14

Rozak, A. 2011. Konstruksi Respons Pembaca terhadap Teks naratif. Cirebon: Unswagati.

Umar, A. 2017. Mengapresiasi Karya Sastra Indonesia. Sumber Penunjang PLPG 2017. Jakarta: Kemdikbud.

Wardani, I.G.A.K, Wihardit, dan Nasoetion. 2004. Penelitian Tindakan Kelas. Jakarta: Universitas Terbuka. 
Sumarjo, Y dan Saini, K.M. 1988. Apresiasi Kesusastraan. Jakarta: Gramedia

Soekanto, S. 1993. Kamus Sosiologi. Jakarta: PT. Raja Grafindo Persada

Susanto. A. 1997. Pengantar Sosiologi dan Perubahan Sosial. Jakarta: Bina Cipta. 